\title{
Figures, Tables, and Maps
}

\author{
FIGURES
}

I.I. Offerings to the goddess Chicome Coatl at Cinteopan revealing the gendered division of labor in Nahua society 2

2.I. Drunkard who transformed into a rabbit 23 2.2. Nahualli forms of a commoner 25

2.3. Calendar reader naming a newborn and explaining his fate 27

2.4. Midwife ritually bathing a baby boy with the symbols of masculinity lying beside the basin 34

2.5. Symbols of femininity introducing text that describes the bathing ritual for a baby girl performed by a midwife 35

2.6. Midwife performing the bathing ceremony 36

2.7. Nudzahui noblemen and noblewomen making offerings at a temple 44

2.8. Xochihuaque, or cross-dressed man and woman 47

3.I. Image submitted to the Holy Office of the Inquisition showing Martín Xochimitl being tried for polygyny with the four sisters who were his "wives" 60 3.2. Marriage prognostication warning of violence 66

3.3. Marriage prognostication warning of violence 67

3.4. Marriage prognostication warning of violence 68

3.5. Cihuatlanque discussing marriage negotiations with a young man 69 


\subsection{Nahua marriage ceremony 72}

3.7. Beginning of indigenous-Christian marriage in $1532 \quad 78$

3.8. Nahua-Christian marriage ceremony 82

4.I. Nudzahui yuhuitayu showing the joint rule of the male yya toniñe (left) and the female yya dzehe toniñe (right) 96

$$
\text { 4.2. Lienzo of Tabaá (detail) } 97
$$

4.3. Land titles showing San Francisco Caxhuacan's leading couples and its patron saint 98

5.I. Ixnextli-Xochiquetzal as the embodiment of sexual transgression and discord II5

5.2. Vagabond shown coming and going II6

5.3. Xochiquetzal with symbols of illicit sex I2I

5.4. Sixteenth-century prostitute, revealing the indigenous association between drinking and sex $\quad$ I 24

5.5. Sixteenth-century depiction of an evil youth who is prone to the vices of drunkenness and lust I25

5.6. Prostitute holding flowers, symbolizing sexual excess and seduction I27

5.7. Prostitute holding flowers and wearing a floral garment I 28

5.8. "Wicked old man" depicted wearing a flowered cape (left) and procurer with flowery speech (right) $\quad$ I28

5.9. Nudzahui primordial couple I 29

5.IO. Feathered serpent in birth scene from a

Nudzahui pictorial manuscript 130

5.II. Tlazolteotl with feathered serpent I3I

5.I2. Tetlanochili, or procuress I 43

6.I. Prognostication warning that adultery would ruin the marriage I5I

6.2. Death by stoning as punishment for adultery $\quad 160$

6.3. Punishment for adultery I6I

6.4. Punishment for adultery I63 
6.5. Pictorial submitted in a land dispute showing a man executed for adultery (bottom left) $\quad$ I64

6.6. Yope custom of biting off the noses of adulterers as punishment for their transgressions 165

7.I. Middle-aged Nahua woman I79

7.2. Merchants, identified by cloth and other precious trade goods I83

$$
\begin{array}{cc}
\text { 7.3. Spinner } & \text { I } 84 \\
\text { 7.4. Tailor } & \text { I85 }
\end{array}
$$

7.5. Man using metate $\quad$ I89

7.6. Man heating a substance over a fire $\mathrm{I} 89$

7.7. Nahua ticitl advising a pregnant woman, before an assembly of household members and kin, on how to take care of herself during pregnancy 195

7.8. Nahua ticitl massaging a pregnant woman's abdomen to position the baby and prepare the mother for birth $\quad 196$

7.9. Nahua ticitl enclosing a woman, whose baby cannot

be delivered, in the temascalli to await death 197

7.IO. Female ticitl in front of Quetzalcoatl 200

7.II. Ticitl attending to victims of a smallpox epidemic $20 \mathrm{I}$

7.I2. Nahuatl-language document with pictorial image presented in a dispute over tribute labor 220

7.I3. Tribute list depicting cloth paid in tribute to Aztec rulers in preconquest times $\mathbf{2 2 2}$

8.I. Mid-sixteenth-century Nahua household showing a married couple and their children 234

8.2. Nahua household and its land 235

8.3. Aztecs' ancient origins, showing a couple in a cave 236

8.4. Woman making dye in the household patio 238

8.5. Mothers and fathers training and disciplining their daughters and sons 240

8.6. Male and female plaintiffs presenting their case to judges 252 
8.7. Women and men appealing to judges in front of Moteucçoma's palace 253

9.I. Six Monkey engaged in warfare 264

9.2. Page from the pictorial manuscript presented in litigation by Tepetlaoztoc over excessive labor demands on the community 269

9.3. Page from the pictorial manuscript presented in litigation by Tepetlaoztoc over excessive labor demands, showing cloth as payment in kind 269

\section{TABLES}

2.I. Fates and personality traits associated with the calendar 28

4.I. Sampling of couples tried for amancebamiento in the archbishopric of Mexico City, I582-I584 IOI

6.I. Punishments for adultery in preconquest times I59

7.I. Nahuatl-language terminology based on toltecatl (artisan) from the Florentine Codex $\quad{ }^{8} 87$

7.2. Nahuatl-language terminology based on imati (be skilled, expert) from descriptions of artisans in the Florentine Codex $\quad$ I87

7.3. Nahuatl-language Terminology based on tlananamactia (make things meet or match) from descriptions of artisans in the Florentine Codex I88

7.4. Nahuatl-language terminology based on tlapalhuia (paint or dye something) from descriptions of artisans in the Florentine Codex I88

7.5. Nahuatl-language terminology based on tliloa (outline in black) and icuiloa (write, paint) from descriptions of artisans in the Florentine Codex I88 7.6. Some Nahuatl terms for midwife I94

7.7. Ticitl identified in Ruiz de Alarcón's I629 treatise on heathen superstitions 203

MAPS

I.I. Central Mexico 5

I.2. Mixteca Alta and Sierra Zapoteca regions of Oaxaca 6 